Tyndale Bulletin 67.1 (2016) 145-160

\title{
ANCIENT ROME'S DAILY NEWS PUBLICATION WITH SOME LIKELY IMPLICATIONS FOR EARLY CHRISTIAN STUDIES
}

\author{
Brian J. Wright
}

\begin{abstract}
Summary
A detailed study on ancient Rome's daily news publication is currently absent in early Christian studies. This article seeks to begin filling this lacuna by surveying the history of this Roman news bulletin and highlighting the sorts of data that must be taken into account in order to determine the publication's subject matter, scope of distribution, and possible relevance for early Christian studies.
\end{abstract}

\section{Introduction}

The Roman government published and distributed a news publication for the populace of the city of Rome before, during, and after the first two centuries of the Common Era (ca. 59 BC - AD 222). ${ }^{1}$ The evidence of such activity is well established by authors writing before,

1 For the purposes of this study, the Latin phrase Acta Diurna will be used as the categorical title for this daily news publication in Rome in order to maintain consistency and alleviate any unnecessary confusion. At the same time, it is important to note that many other terms were used to refer to this same news bulletin in both Latin (e.g. Acta Publica, Acta Urbana, Acta Rerum Urbanarum, Acta Populi) and

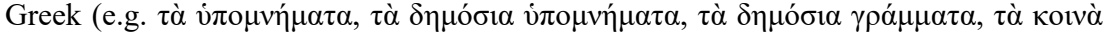

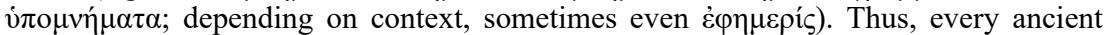
text cited will not use the same language or phrase to denote this publication, and context will still be needed to justify the identification with this publication. Moreover, one must be cautious in assuming just the word acta is always referring to an urban gazette because that assumption is not always true. The noun-form acta can refer to other documentary sources. Also for the purposes of this study, unless otherwise noted, all ancient quotations will be taken from Harvard's digital Loeb Classical Library. 
during, and after the same era. ${ }^{2}$ Although scholars have known about this news bulletin for a long time now, ${ }^{3}$ it appears to have dodged any substantial academic treatment in early Christian studies. ${ }^{4}$ Four broad examples of such minimal scholarly discussion ought to suffice here.

First, David Aune offers only one sentence on Acta in his reference work. ${ }^{5}$ Yet even then, he appears to be strictly referring to one particular version of Acta, the acta senatus, and not to any others. Second, Brill's New Pauly online platform is too narrow in scope. It does not include some of the classic works on the topic in various languages. Gessel's article in English (see note 2) and Behrisch's essay in German (mentioned below) are absent, just to name two.

Third, Craig Keener references the topic in his recent Acts commentary when he writes in a footnote: 'The genre [of the Book of Acts] should not be confused, because of its English title, with Latin acta, which could be gazettes (including official events, decisions, lawsuits, and speeches) or lists of emperors' enactments. ${ }^{\prime 6}$ But besides referencing two general studies on the broad category of Acta in the same footnote, he does not pursue its relevance to Luke-Acts in any more detail, such as the likelihood that the author, who does research

2 The standard work is still Ernst Willibald Emil Hübner, De Senatus populique Romani actis scripsit Aemilius Rübner (Lipsiae: in aedibus B. G. Teubneri, 1859). The now classic concise discussion, though often missing in more recent works, is H. L. Van Gessel, 'Acta Urbis - Ancient Rome's Local Paper', International Communication Gazette 16.1 (1970), 88-104. Cf. Attilio Mastino, Gli 'Acta Urbis': Il 'giornalismo' nell'antica Roma (Urbino: Montefeltro, 1978).

3 Beyond mere historical treatments, for example, Guido Gonella published 1,076 articles between 1933 and 1940 in L'Osservatore romano under the rubric 'Acta Diurna', which highlight some of the major concerns of the Catholic Church in the 1930s. Even more, R. I. W. Westgate published a laudatory academic review of a contemporary 'Acta Diurna' being published and used in England and American schools in order to teach students Latin. He states that it is: 'A first-class Latin newspaper ... which can be recommended without reserve to all who teach Latin. ... It is written in good Latin that would have been intelligible in the days of the Roman Republic.' He goes on to say that it is also being appreciated by more mature students, such as graduate students, 'who are trying to learn Latin in a hurry' ('Acta Diurna', Classical Weekly 45.8 (1952), 121).

4 This absence further supports Larry Hurtado's observation regarding the lack of familiarity among some biblical scholars of book culture in the first few centuries of the Common Era. See Larry Hurtado, 'Oral Fixation and New Testament Studies? "Orality", "Performance" and Reading Texts in Early Christianity', NTS 60 (2014), 321-40.

5 The Westminster Dictionary of New Testament and Early Christian Literature and Rhetoric (Louisville, KY: Westminster John Knox, 2010), 2.

6 Acts: An Exegetical Commentary, Volume 1: Introduction and 1:1-2:47 (Grand Rapids, MI: Baker Academic, 2012), 89n320. 
and claims to work like an ancient historian, used such Acta for identifying officials, summarisng trial scenes, and examining records of speeches. ${ }^{7}$ Fourth, in William V. Harris's influential study on ancient Graeco-Roman literacy levels, ${ }^{8}$ which has significantly influenced New Testament research, he never identifies or discusses its relevance to ancient literacy. ${ }^{9}$ The closest he comes to discussing any Acta is when he uses the Acta Senatus (i.e., proceedings of the Senate) as an example of the expanded function of writing from political life.

The goal of this essay, then, is twofold. First, it will highlight some significant details regarding the history of this Roman news publication, especially the features pertaining to the first two centuries AD. Second, it will briefly examine the subject matter and scope of distribution of these texts in order to further explore how this additional literary development intersected with the wider Roman imperial world. By doing so, we may draw a more reliable picture regarding ancient media and the place of texts in early Christianity. While these two ends comprise the main goal, I will also note some likely implications this evidence has on some topics in early Christian studies, even though a full treatment of each is outside the scope of this brief study, such as the frequency of divorce as implied by 1 Corinthians 7 , the expectation of literary works being broadly disseminated, and the rapid spread and impact of idioms via written material.

\section{Historical Survey}

In 1979, Barry Baldwin noticed that the main academic works examining the Acta Diurna were almost all from the 19th century, 'restricted by and large to the older German and French manuals and to

7 I owe these three observations to Ben Sutton, who has since presented an unpublished paper on Luke's historiographical technique ('Suetonius, Asconius, and Luke: Roman Authors and the Consultation of News Reports', presented at the annual meeting of the Institute of Biblical Research in Atlanta, Georgia on 20 November 2015).

8 William V. Harris, Ancient Literacy (Cambridge, MA: Harvard University Press, 1989).

9 He does, however, footnote one key text (Suetonius, Julius 20.1) explicitly mentioning the Acta Diurna (Harris, Literacy, 206n158). On the importance of incorporating additional evidence in ancient literacy studies, as well as a few problems regarding the widely held assumptions operative among scholars working in early Christian studies, see my article, 'Ancient Literacy in New Testament Research: Incorporating A Few More Lines of Enquiry', TJ 36.2 (2015), 161-89. 
theses and journals not readily accessible'. ${ }^{10} \mathrm{He}$ went on to suggest that these same treatments 'do not always provide accurate or complete assemblages of the primary information'. ${ }^{11}$ Almost 20 years later, in 1995, Lars Behrisch saw a similar picture. After noting the heated debates in German Classical Studies during the 19th century and the numerous publications produced on the subject during the same period, he claims that little interest can be found in publications in the 20th century - as if to suggest that a final conclusion has been reached. Similarly to Baldwin, he states: 'Nevertheless, the problem is far from resolved. ' ${ }^{2}$ Shortly thereafter, in 1997, Peter White ambitiously denied that we have cogent answers to many of the questions regarding this news publication, and boldly concluded that it is a near certainty that he [Caesar] did not publish anything resembling a modern newspaper'. 13

Although this essay will not be addressing the historical debate concerning the Acta Diurna, it will outline some major details of its literary history before discussing its contents and distribution.

The Latin term Acta in its broadest sense means 'the things that have been done', ${ }^{14}$ or more simply, 'events'. Without any additional qualifiers, these events could - and did - include public and private activities; secular and sacred matters; government and civilian affairs. With additional qualifiers, these events had a narrower and even more specialised meaning. The Acta Militaria refers to published military events, ${ }^{15}$ the Acta Senatus indicates published senatorial events, ${ }^{16}$ and

10 Barry Baldwin, 'The acta diurna', Chiron 9 (1979), 189-203, esp. 189.

11 Baldwin, 'The acta diurna', 189.

12 'Dennoch ist die Problematik keineswegs abgeschlossen' (Lars Behrisch, 'Die "acta diurna": eine römische Staatszeitung?', Altertum 41.1 [1995], 55-68, esp. 55.)

13 Peter White, 'Julius Caesar and the Publication of Acta in Late Republican Rome,' Chiron 27 (1997), 73-84, esp. 84. Suffice it to say here that White's treatment is extremely narrow and provides too many historical oversimplifications to frame an accurate picture of this ancient news publication. For example, White seems to make Cicero and Suetonius representative of the entire discussion. He never mentions Petronius's parody. He only deals with the Latin side of the equation. He rarely interacts with international scholarship. He never mentions the senator appointed by Tiberius to edit the Acta Senatus or the procurator ab a. urbis. He does not address comments made by non-elite authors. Moreover, he only covers the last two centuries BC. For reasons such as these, I reject his overall conclusion.

14 John Percy Vyvian Dacre and Andrew William Lintott, 'Acta', in The Oxford Classical Dictionary, 4th ed., ed. Simon Hornblower and Antony Spawforth (Oxford: OUP, 2012), 10.

15 The first-century papyrus PSI 13.1307 is one example. For further details, see J. F. Gilliam, 'Notes on PSI 1307 and 1308', Classical Philology 47.1 (1952), 29-31. Cf. 
the Acta Triumphorum denotes the published triumphs of emperors. ${ }^{17}$ The main qualifier for the purposes of this study is diurna, which simply means 'daily'. Thus, the Acta Diurna represents published 'daily events'. ${ }^{18}$ Though there are no authentic fragments of these specific kinds of acta, ${ }^{19}$ and thus no physical features to discuss, there are ample references to them in ancient authors (again, by various nomenclature). Both Tacitus and Suetonius used these Acta as sources for information about the Empire's earlier emperors when they were writing their histories of Rome. ${ }^{20}$ Some authors, like Asconius, even

Sergio Daris, 'Osservazioni AD alcuni papyri di carattere militare', Aegyptus 38 (1958), 151-58, esp. 157-58; Sergio Daris, 'Note di lessico e di onomastica militare', Aegyptus 44 (1964), 47-51. For other examples from inscriptions and ancient authors see M. Léon Renier, Inscriptions Romaines de l'Algérie (Paris: Imprimerie Impériale, 1855); J. F. Gilliam, 'Some Military Papyri from Dura', in Yale Classical Studies: Volume 11, ed. Harry M. Hubbell (New Haven, CT: Yale University Press, 1950), 171-252, esp. 209-252.

16 The bulletin of daily news was almost exclusively a private affair before Julius Caesar made it regular and official in $59 \mathrm{BC}$. Although private publications continued, he ordered that these occasionally published Acta were to be published daily for mass consumption under the authority of the government from the court reporters' notes (e.g. Seneca the Younger Apocolocyntosis 9). After Julius Caesar's death, a custom arose that future emperors (and their magistrates every January) were to swear to keep and respect all previous Acta Senatus from their predecessors (e.g. Dio Cassius 47.48; cf. 37.20); with a few exceptions (e.g. Dio Cassius 56.33). For inscriptional evidence of how emperors dealt with the acta of their predecessors, see Benjamin Wesley Kicks, 'The Process of Imperial Decision-Making from Augustus to Trajan' (Ph.D. dissertation, Rutgers, 2011), 86-91, the case study regarding the Epistula Domitiani ad Falerienses. For additional details and texts, see, among others, William Smith, William Wayte, and G. E. Marindin, eds., A Dictionary of Greek and Roman Antiquities (London: John Murray, 1890); Harry Thurston Peck, ed., Harper's Dictionary of Classical Literature and Antiquities (New York: Cooper Square, 1965), 14-15.

17 Pliny, Naturalis historia. 37.6.

18 Too much emphasis should not be placed on the word 'daily' since it is possible that it could mean 'everyday' events, as in 'current events.'

19 I say 'authentic' here because some forgeries have been published. For example, eleven fragments of the Acta Diurna were published in 1615 by Pighius, and defended by Dodwell. Though the fragments were exposed as a fifteenth century forgery (by Wesseling, Ernesti et al.), some scholars still attempted to defend their authenticity at least as far as 1844; with Lieberkühn. For more details and background to this story, see Wilhelm Sigismund Teuffel, A History of Roman Literature: Volume One, The Republican Period, trans. Wilhelm Wagner (London: George Bell and Sons, 1873), 381. Cf. Hermann L. G. Heinze, 'De Spuriis Actorum Diurnorum Fragmentis Undecim: Fasciculus Prior' (Ph.D. dissertation, University of Greifswald, 1860), 11-24; Andrew Lintott, 'Acta Antiquissima: A Week in the History of the Roman Republic,' Papers of the British School at Rome 54 (1986), 213-28.

20 A. W. Mosley, 'Historical Reporting in the Ancient World', NTS 12.1 (1965), $10-26$. 
state that they are quoting certain Acta verbatim (Asconius 44). ${ }^{21}$ There is also evidence of other published Acta. For instance, there are good reasons to regard an $\mathrm{AD} 13$ fragment as coming from the Acta Alexandrorum. ${ }^{22}$ We turn now to such types of evidence.

Acta were not the only news publications of their kind. There is evidence of many hand-written daily news publications from the wider world during this same period. China had an official daily news publication called the Di-Pao, which also existed before, during, and after the first two centuries AD (i.e. the Han Dynasty ca. 206 BC - AD 220). ${ }^{23}$ Likewise, there were other daily Acta beyond the one prepared and disseminated by the Roman government. Mary Beard writes: 'The priests of the Arval Brotherhood at Rome during the first three centuries of the empire kept a detailed written record [i.e., the Arval Acta] of their ritual and cult organization, year by year and day by day. ${ }^{24}$ This daily Acta also existed before, during and after the first two centuries (i.e. $21 \mathrm{BC}-\mathrm{AD} 304$ ). As for the extant evidence of the Arval Acta, Beard goes on to state: 'They survive in considerable quantity - Henzen's edition of the texts, for example, occupies some 200 pages, and more have been found since that publication in 1874. ${ }^{25}$

There were also other Acta frequently published around celebrations, festivals, and games, such as the Acta Ludorum Saecularium (i.e., news publication of the secular games). ${ }^{26}$ One prime example attesting this is the inscription discovered in 1890 written shortly after a festival in 17 BC (i.e., the fifth secular games: Ludorum

21 For a discussion of this text and a few others in Asconius, see G. V. Sumner, 'Asconius and the Acta', Hermes 93.1 (1965), 134-36.

22 The text and an assessment can be found in E. Lobel and E. Turner, eds., The Oxyrhynchus Papyri: Volume 25 (London: Egyptian Exploration Fund, 1959), 104 for the assessment and 108-109 for the text.

23 Among other studies, see Jian-zhong Zhou, 'Documenting the Earliest Chinese Journals', Journal of Library and Information Sciences 27.2 (2001), 19-24; Paul T. H. Huang, 'Ti-Pao: The Earliest Chinese Newspaper', Canadian Library Journal 27.2 (1970), 96-101; Pan Ku, The History of the Former Han Dynasty, trans. Homer H. Dubs (Baltimore: Waverly Press, 1938).

24 Mary Beard, 'Writing and Ritual: A Study of Diversity and Expansion in the Arval Acta', Papers of the British School at Rome 53 (1985), 114-62, esp. 114.

25 Beard, 'Writing and Ritual', 120.

26 See among others Aline Abaecherli Boyce, 'Processions in the Acta Ludorum Saecularium', Transactions and Proceedings of the American Philological Association 72 (1941), 36-48; John Scheid, Quand faire, c'est croire: Les rites sacrificiels des Romains (Paris: Aubier, 2005). 
Saecularium Quintorum). ${ }^{27}$ The inscription consists of 168 lines written in majuscule script, and has already corrected several previous assumptions. For example, in addition to noting the mistakes found in various encyclopedias and dictionaries prior to its discovery, Moses Slaughter points out this inscription's significance for other ancient texts, such as Horace, and even our historical reconstructions of certain events. ${ }^{28}$ He writes:

The discovery of the Acta is of great importance for the commentary on the Carmen Saeculare, substituting positive and accurate statements for conjecture. Even so good an editor as Gesner could cite authorities who imagined that there was presented at this festival a sort of Horatian drama in five acts made up of selected odes and sung at various times and places during the celebration. The discovery of the Acta has made such vagaries impossible. ${ }^{29}$

As for the Acta Diurna more specifically, although they were still published and controlled by the government, ${ }^{30}$ their broad scope and wide distribution created an additional sense of community and identity across the Empire. Even in colloquial letter writing, the news publication was being used as the basis for some analogies. Seneca the Elder in the first century BC shares a story about one man's style of speaking, and his favorite analogy for the man's manner of speaking was the one given by Scaurus, who said he speaks as if he 'reads the newspaper into your ear'. ${ }^{31}$ As this study will argue more extensively below, both the widespread dissemination and broad range of contents seem to have influenced more people and areas than previously examined.

27 Rodolfo Lanciani, 'The Pageant at Rome in the Year 17 B.C.', Atlantic Monthly (1892), 145-52.

28 Moses S. Slaughter, 'The Acta Ludorum saecularium quintorum and the Carmen Saeculare of Horace', Transactions of the American Philological Association (18691896) 26 (1895), 69-78.

29 Slaughter, 'The Acta', 71.

30 For a concise discussion on how the Acta Diurna may have been abused at times by emperors and others for the purposes of propaganda, see Baldwin, 'The acta diurna'.

31 Seneca the Elder, Controversiae 2.1.35. 


\section{Widespread Literary Development}

The goal here is to describe and underscore a few ways in which the Acta Diurna displays a widespread literary development during the first few centuries $\mathrm{AD}$, while also keeping in mind some ways this data may impact early Christian studies. The central point this portion of the study seeks to illustrate by presenting and emphasising this widespread literary development is the idea that reading, writing, and distribution may have been more widespread and may have included more people than has often been accepted or acknowledged in early Christian studies. Thus, one direct application this would have on early Christian studies is how other documents, such as Paul's letters or the Gospels, could be expected to also spread easily and experience wide readership. ${ }^{32}$

In order to begin demonstrating the relevance of this data for early Christian studies, especially since the Acta Diurna has never been incorporated into these dialogues, this section will purposefully target only two key aspects of Rome's daily news publication: (1) subject matter; and (2) scope of distribution.

\subsection{Subject Matter}

It must be acknowledged that an inter-textual analysis of the references to the Acta Diurna from authors writing in the first two centuries AD will not solve the more difficult problem of source analysis. At the same time, examining these texts can illuminate certain aspects of the Acta Diurna with greater historical clarity, bringing scholars at least a little deeper into the source strata. This first part of this examination seeks to determine what types of information the Acta Diurna probably contained in order to better gauge its readership.

Rome's daily news publication included events such as births, marriages, deaths, and festivals. ${ }^{33}$ It would update people on agricultural yields, building projects, and financial records. One of the best examples of the kinds of content the news publication would have

32 See among others Lars Hartman, 'On Reading Others' Letters', HTR 79 (1986), 137-46, esp. 139.

33 This does not mean the Acta Diurna was the only, or even primary source for obtaining this information. Fritz Schulz examines Roman registers of births and birth certificates and seems confident at times to be able to distinguish when a literary passage is referring to the official Roman register and not the Acta Diurna (e.g. 'Roman Registers of Births and Birth Certificates: Part II', JRS 33 [1943], 55-64). 
included, and which would have been familiar to most people, can be seen in the writings of Gaius Petronius, Nero's courtier. Petronius writes about a dialogue between Trimalchio and a clerk. The clerk in this story informs Trimalchio just like the daily news publication would inform the people. The entire episode (Satyricon 53) is worth quoting in full:

But a clerk quite interrupted his passion for the dance by reading as though from the city's daily gazette: 'July the 26th. Thirty boys and forty girls were born on the estate at Cumae which is Trimalchio's. 500,000 bushels of wheat were carried from the threshing floor to the granary. Five hundred oxen were broken in. On the same date: the slave Mithridates was led to crucifixion for having damned the soul of our lord Gaius. On the same date: ten million sesterces which could not be invested were returned to the strong-box. On the same day: there was a fire in our gardens Pompeii, which broke out in the house of Nasta the bailiff.' 'Stop', said Trimalchio, 'When did I buy any gardens at Pompeii?' 'Last year', said the clerk, 'so that they are not entered in your accounts yet'. Trimalchio glowed with passion, and said, 'I will not have any property which is bought in my name entered in my accounts unless I hear of it within six months.' We now had a further recitation of police notices, and some foresters' wills, in which Trimalchio was cut out in a codicil; then the names of bailiffs, and of a freedwoman who had been caught with a bathman and divorced by her husband, a night watchman; the name of a porter who had been banished to Baiae; the name of a steward who was being prosecuted, and details of an action between some valets. ${ }^{34}$

Though this one episode does not provide an exhaustive list of what this daily news publication contained, it does at least provide an illustrative one. ${ }^{35}$ In fact, his parody loses any rhetorical impact if it completely lacks correlation to reality. One may still argue that a special citation suggests irregular use, but Petronius seems to assume his readers will identify with his analogy - recognising the reported categories as given in Rome's news publication (births, deaths, finances, etc.). Taking this story one level further, Kenneth Rose argues

34 Petronius, Seneca Apocolocyntosis, LCL 15, trans. Michael Heseltine and W. H. D. Rouse (Cambridge, MA: Harvard University Press, 1969), 109-111 (italics added).

35 Though we cannot know exactly what all these news publications contained, I essentially agree with John Jackson, who said, 'The style and matter [of these government journals] may be fairly well conjectured' (Tacitus, The Histories Books IV-V and Annals Books I-III, LCL 249, trans. Clifford H. Moore and John Jackson [Cambridge, MA: Harvard University Press, 1979], 526n1). Besides the text from Tacitus he is translating and discussing here (Annales 3.3), he also points to Petronius's Satyricon 53 and Annales 13.31; though there are certainly many other texts to incorporate (e.g. see Annales 16.22 below). 
that there is an important non sequitur in this exchange when read in the broader context of the whole work. ${ }^{36}$ In essence, he suggests that Trimalchio is trying to imitate Imperial customs, as if his vast estates were organised like a miniature Rome. Rose maintains that Petronius's audience would not have missed this complex joke.

Advertisements and human-interest stories also existed in these daily news bulletins. Pliny the Elder shares several stories he read in the Acta Diurna. One story was about the faithfulness of Titius Sabinus's dog. Even after the man was put to death under Nero, the dog stayed by his side. When the corpse was thrown into the river, a large group of people witnessed the dog jumping in and trying to keep the body afloat. ${ }^{37}$ Elsewhere, Pliny the Elder recounts some details he read in the daily news publication about a story involving a conflict between two opposing parties at a funeral. ${ }^{38} \mathrm{He}$ used the news story as an example in his writings of an unhappy death. Another story he shares from the gazette is about a court scene. He says that it stated, 'while Milo was pleading a case in court it rained baked bricks' ${ }^{39}$ If such trial depictions were readily available to the public, as the evidence here and elsewhere seems to suggest, it is not difficult to imagine New Testament authors having equal access to such gazettes in order to set up or discuss their trial scenes. ${ }^{40}$

The news items also included cover-ups, accidents, fires, divorces, and other miscellaneous information. Dio Cassius shares a story he read in the daily news publication about an architect who saved a portico from collapsing. The most interesting part of the story to Cassius, however, was not the rescue of a structure. Rather, he observed that Emperor Tiberius would not let the man's name be published in the daily news publication because Tiberius was jealous of the architect's great accomplishment. ${ }^{41}$

36 Kenneth F. C. Rose, 'Trimalchio's Accountant', Classical Philology 62.4 (1967), 258-59.

37 Pliny the Elder, Naturalis historia 8.61.

38 Pliny the Elder, Naturalis historia 7.53.

39 Pliny the Elder, Naturalis historia 2.57.

40 For other ancient evidence of official court proceedings and their relation to early Christian studies, see Bruce W. Winter, 'Official Proceedings and the Forensic Speeches in Acts 24-26', in The Book of Acts in Its Ancient Literary Setting, ed. Bruce W. Winter and Andrew D. Clarke (Grand Rapids, MI: Eerdmans, 1993), 305-336.

41 Roman History 57.21.5. It also may be worth noting that this published news story is somewhat reminiscent of, and has many actual and conceptual similarities to, the 
Speaking about the broad influence of Rome's daily news bulletin, Seneca the Younger argues, 'now, since every gazette has a divorce case, they [the Roman populace] have learned to do what they used to hear so much about'. ${ }^{42}$ Meaning, he laments the fact that the general population was seeing a list of divorces daily in the news publication, and that overtime they grew accustomed to it. This asserted frequency of divorce also highlights the importance of Paul's discussion on divorce in 1 Corinthians 7.43

The publication's frequency and broad readership also contributed to the idioms of the day. For instance, Quintilian suggests that phrases such as 'wounded at heart (saucius pectus) become familiar in the public gazette'. ${ }^{44}$ This is certainly suggestive of how other contemporary idioms, as well as some Christian ones, ${ }^{45}$ may have become popularised: via written material.

Interestingly, there seems to be nothing of events from elsewhere in the empire. Though using an argument from silence is always risky, it can be pressed into service here since all the evidence seems to suggest the Acta Diurna was strictly a Roman news publication. The closest an author comes to insinuating that this daily gazette only contained Roman news is when Valerius Maximus in the first century AD discussed the censorship of Fabricius Luscinus. He grieves over the fact that certain events covered in the Roman news publication appeared so severe and terrible that it was as if it was a daily news publication of another city. ${ }^{46}$ If it is true that foreign events were not included, then several texts referring to its widespread distribution especially among Roman citizens living abroad - make more sense.

\subsection{Scope of Distribution}

Both elite and non-elite authors affirm the expectations of widespread distribution by explicitly stating that their works were read far and

\footnotetext{
account where the Lukan Jesus shares a current event about the tower in south Jerusalem falling on eighteen people (Luke 13:4).

42 Seneca the Younger, de beneficiis 3.16.

43 For further information on the social and literary context of divorce and Paul's discussion of it, see David Instone-Brewer, Divorce and Remarriage in the Bible: The Social and Literary Context (Grand Rapids, MI: Eerdmans, 2002), 189-212.

44 Quintilian, Institutio oratoria 9.3.17.

45 That early Christians did to some degree create their own idioms and vocabulary, see C. F. D. Moule, An Idiom-Book of New Testament Greek, 2nd ed. (Cambridge: Cambridge University Press, 1968).

46 Memorable Doings and Sayings 2.9.4.
} 
wide. Propertius claims a worldwide reputation for his writings, 'renown that has travelled to the wintry northlands' ${ }^{47}$ Pliny the Elder held that Marcus Varro wrote a book and 'despatched it all over the world, enabling his subjects to be ubiquitous, like the gods' ${ }^{48}$ Martial, who was a non-elite, claims that his works are 'famous throughout the world', ${ }^{49}$ read even among soldiers in distant border districts. ${ }^{50}$ Ovid claims to be read 'wherever the world extends ... Across the land, across deep waters' ${ }^{51}$ even when he was exiled to the east. In fact, he believes that because of the extent of his readership throughout the world his fame will never die even when he physically dies, for which he thanks all his readers, 'But whether through favour or by very poetry I have gained this fame, 'tis right, kind reader, that I render thanks to thee.' 52

Certainly, if these texts are individually isolated from each other or divorced from their surrounding contexts, an argument can be made that all these authors were merely exaggerating. Yet the picture they paint seems to fit well with the other evidence we have, such as the Acta Diurna. Meaning, beyond the writings of individual authors there is a strong indication that the Acta Diurna's scope of distribution was also widespread. This assumed ability to spread news through written material, even to far flung locations, is relevant for understanding the circulation of literature within early Christian communities (Col. 4:16; 1 Thess. 5:27; 1 Tim. 4:13; James 1:1; Rev. 1:3).

In $62 \mathrm{BC}$, three years prior to Julius Caesar's establishment of the Acta Diurna, Cicero states that he made sure certain essential news items were disseminated broadly. Once he knew the information was entered into the official public records, he states:

[I] immediately ordered it to be copied by all the clerks, distributed everywhere and given full publicity and made known to the Roman people. I broadcast it throughout Italy and despatched it to all the provinces. I did not want anyone to be ignorant of the information which had been responsible for the salvation of us all. I say, therefore, that

\footnotetext{
47 Propertius 2.7.17-18.

48 Pliny the Elder, Naturalis historia 35.2.11.

49 Epigrams 7.17.

50 Epigrams 5.5.

51 Tristia 4.9.20-25.

52 Tristia 4.10 .130$.
} 
there is no place in the whole world where the name of the Roman people is known that has not received a copy of this information. ${ }^{53}$

Interestingly, he seems to make a distinction between several groups of people when he says, 'distributed everywhere and given full publicity and made known to the Roman people'. He is probably referring to both civil servants and the general population. Either way, he explicitly states that certain news was able to be disseminated broadly, and he constantly assumes throughout his writings - especially in his Letters to Family - that people traveling abroad received them.

The physical distribution of news also suggests that traditional meeting places were no longer enough to keep up with all the important events, and that the requirements of travellers and those Roman citizens living abroad demanded broad dissemination. ${ }^{54}$ Some people, particularly the elite, even had the daily news publication delivered straight to their homes via the government-sponsored postal service though certainly not on a daily basis. One may recall the statement made centuries beforehand by Xenophon of Athens about the new Persian postal service:

We have observed still another device of Cyrus [when he inaugurated a postal service] to cope with the magnitude of his empire; by means of this institution he would speedily discover the condition of affairs, no matter how far distant they might be from him: he experimented to find out how great a distance a horse could cover in a day when ridden hard but so as not to break down, and then he erected post-stations at just such distances and equipped them with horses and men to take care of them; at each one of the stations he had the proper official appointed to receive the letters that were delivered and to forward them on, to take in the exhausted horses and riders and send on fresh ones.

They say, moreover, that sometimes this express does not stop all night, but the night-messengers succeed the day-messengers in relays, and when that is the case, this express, some say, gets over the ground faster than the cranes. If their story is not literally true, it is at all events undeniable that this is the fastest overland travelling on earth; and it is a fine thing to have immediate intelligence of everything, in order to attend to it as quickly as possible. ${ }^{55}$

53 Cicero, Pro Sulla 42-43.

54 Erik Holmberg noted this idea in his dissertation, 'Zur Geschichte des Curcus Publicus' (Ph.D. dissertation, Uppsala, 1933), 17.

55 Xenophon, Cyropaedia 8.6.18. 
This type of service did not stop after the days of Cyrus. General edicts even went out in order to deal with all the problems regarding transport vehicles. ${ }^{56}$ In fact, the entire postal enterprise grew and developed in the ancient world. According to Suetonius (Divus Augustus 49:3), Augustus significantly improved the postal service, prompting Stephen Llewelyn to conclude: 'Though the system evolved and developed over time its basic structure is already well attested in the first century AD. ${ }^{57}$ There are also many other statements regarding the existence and expansion of various postal systems in subsequent centuries. Narrowing the search to just the first few centuries AD, I will provide three examples here. Pliny the Younger writes: 'Up to now, Sir, I have made it a fixed rule not to issue anyone a permit to use the Imperial Post unless he is travelling on your service, but I have just been obliged to make an exception. ${ }^{58}$ Tertullian states: 'O sluggish messengers! $\mathrm{O}$ sleepy-headed postal service! it was your fault that Cybele failed to hear earlier of the Emperor's death, to prevent Christians from laughing at such a goddess!' ${ }^{59}$ Philostratus of Athens records: 'Some time later a man traveling by the express postal service arrived in Gadeira, telling them to perform sacrifices for good news and celebrate Nero as a triple Olympic winner. ${ }^{60}$

None of these texts, or any others to my knowledge, suggest that this was the only or even primary means of delivery. It still seems most probable that only certain elite would have had them delivered to their doorsteps, and even though the postal service delivered news broadly, it would have only selected certain drop-off locations and could not have delivered it daily. At the same time, the evidence does seem to

\footnotetext{
56 For a concise discussion of one such edict, issued sometime between 25 January 49 and 24 January 50, see Werner Eck, 'Administrative Dokumente: Publikation und Mittel der Selbstdarstellung', in Die Verwaltung des Römischen Reiches in der Hohen Kaiserzeit: Ausgewählte und erweiterte Beiträge II (Basel: Reinhardt, 1998), 359-81, esp. $362 \mathrm{n} 12$.

57 Stephen Llewelyn, 'Sending Letters in the Ancient World: Paul and the Philippians,' TynBul 46.2 (1995), 337-56, esp. 341. Llewelyn also states that evidence is sparse for a private use of the postal service. Granted, but there are still a few more texts he does not discuss or cite that may suggest it. Beyond the Pliny example below, here are just a few such texts that would also need to be brought into the discussion: Historia Augusta (Pertinax 1.6), Pliny the Younger (Letters 2.10.45), Libanius (Oration 1.14), Fronto (Correspondence, Volume I [LCL 112; trans. C. R. Haines; Cambridge, MA: Harvard University Press, 1919], 159).

58 Pliny the Younger, Epistulae 10.120.1.

59 Tertullian, De spectaculis 25.6-7.

60 Life of Apollonius of Tyana 2.5.8.
} 
suggest that there was a greater familiarity with the contents of the paper among a broader geographical terrain than merely major cities, and among a wider group of people than merely the elite. This assessment is also supported via the parodies referring to them, analogies drawn from them, idioms developed within them, and contents covered by them. Moreover, it seems doubtful that the government would go through all the trouble of publishing and editing a daily work - not to mention accruing the daily cost of producing and disseminating it - if the overwhelming majority of people would not receive it and could not read it.

Speaking of readership, there are several indications as to the types of people who may have read this daily news publication in addition to the arguments mentioned above. For instance, it is often spoken of as the news for the masses. Tacitus states: 'The journal of the Roman people [i.e., Diurna populi Romani], is scanned throughout the provinces and armies with double care for news of what Thrasea has not done!' ${ }^{11} \mathrm{He}$ argues elsewhere that the time of Nero and Lucius Piso deserves little remembrance, 'although, in accordance with the dignity of the Roman people, it has been held fitting to consign great events to the page of history and details such as these [the building of the amphitheatre in the Campus Martius] to the urban gazette' ${ }^{62}$ Speaking about both contents and distribution, Suetonius suggests that Emperors could quickly gain public support in part because of the Roman daily news publication. When Claudius became Emperor, Suetonius says there was no problem for him to get the publications he formulated before becoming Emperor generally accepted once he took office. He concludes: '[Claudius's writings] may still be seen in numerous books, in the daily gazette, and in inscriptions on public buildings. ${ }^{63}$

While more examples could be offered, the evidence cited here sufficiently demonstrates that the Acta Diurna was a widespread literary development. A more extensive treatment would be necessary to provide a more precise answer, but we can cautiously infer from a variety of texts that many people over a broad area received and read

61 Tacitus, Annales 16.22.

62 Tacitus, Annales 13.31. Cf. Annales 3.3, where he indicates two places he assumed he could have found certain details of a story: 'I fail to discover, either in the historians or in the government journals, that the prince's mother, Antonia, bore any striking part in the ceremonies, although, in addition to Agrippina and Drusus and Claudius, his other blood-relations are recorded by name.'

63 Suetonius, Divus Claudius 41. 
the Acta Diurna. This selected evidence alone does not provide a definitive answer regarding the entire scope of contents or geographical distribution of this daily news publication. A majority of people can know the contents of a literary work without having the ability to read it themselves, for example. At the same time, it does reveal another literary development that appears to have been widespread both geographically and among different socio-economic levels of society. To put this all another way, the Acta Diurna displays another literary development among an already expanding book culture and increasing demand for written texts during the first few centuries $\mathrm{AD}$ and needs to be included in future early Christian studies.

\section{Conclusion}

The aim of this article was twofold. First, this study sought to highlight some significant historical details regarding ancient Rome's news publication due to its neglect in early Christian studies. Second, it attempted to assess the contents and distribution of this literary development. While the brief survey of these two areas did not provide any conclusive answers, it did collectively identify a largely unexplored field in early Christian studies that should receive greater consideration in the future. At the same time, a few tentative conclusions were drawn. More people probably participated in the literary culture of the day than has been generally accepted or acknowledged in early Christian studies. The contents of this daily news bulletin were broad. Its distribution was far and wide. It was explicitly designed for the general population. Moreover, several likely implications for early Christian studies were noted throughout this examination, such as the expected diffusion of apostolic writings, the likely access to such gazettes by certain NT authors, and the pervasiveness of divorce as implied in 1 Corinthians 7 . In light of these general observations, NT scholars may need to rethink certain connections between fields of study such as literacy, textuality, and orality, as well as reexamine certain biblical passages potentially affected by such evidence. ${ }^{64}$

64 I want to thank the anonymous reviewers of Tyndale Bulletin for offering several suggestions on how to enhance this article, as well as for identifying some additional implications to consider for early Christian studies. 